International Journal of English Literature and Social Sciences
Vol-6, Issue-5; Sep-Oct, 2021
Journal Home Page Available: https://ijels.com/
Journal DOI: $10.22161 /$ ijels

\title{
Serfdom in Tsarist Russia and the Underground Man
}

\author{
Koyel Dasgupta ${ }^{1}$, Rajarshi Mukherjee ${ }^{2}$
}

${ }^{1}$ Department of English, Savitribai Phule Pune University, India

${ }^{2}$ Assistant Professor of Department of English, Shyampur Siddheswari Mahavidyalaya, India

Received: 19 Sep 2021; Received in revised form: 19 Oct 2021; Accepted: 26 Oct 2021; Available online: 31 Oct 2021

(C)2021 The Author(s). Published by Infogain Publication. This is an open access article under the CC BY license

(https://creativecommons.org/licenses/by/4.0/).

\begin{abstract}
In this paper we shall evaluate the Underground Man from Notes from Underground in the light of Russian Serfdom mainly from the psychological (rational and consciousness), social, economic and sexual perspectives. Serfdom in Russia, even though was not absolute slavery but the serfs were controlled by the masters or the landlords. Notes from Underground was published in 1864 and Tsar Alexander II of Russia abolished Serfdom in 1861 however, the account of the events of his younger age which the Underground Man narrates at the age of forty was a time when Serfdom was very much prevailing in contemporary Russia. From Psychological and Social points of view, the Underground Man is constantly trying to defy the ideas of rationalism and that of a Utopian society painted by Chernyshevsky in his What is to be Done? where rationality and logic preponderate. This, is indeed an attempt on his part to escape from the control of reason and not be a serf to rational thinking. However, concomitantly he is bonded to his over-consciousness and we can acknowledge instances of this in the novella. He denies logic and asserts free will but he talks about pleasure in pain and even questions whether man is fond of suffering and the idea that surfaces here is that whether in opposing a Utopian society based on reason he is actually supporting the foundation stones of a Dystopian society. From an Economic perspective, he is a serf to the civil service job which he is not fond of and he actually detests his colleagues but he cannot resign from it for the economic support it provideseven if that is little. However, he reluctantly spends money even when he is economically poor at times and the question, we ask here is that is it an instance where he is trying to momentarily escape from the control and embrace the freedom, he does not consistently enjoy much like those serfs who escaped on their way to St Petersburg to build the new city under Tsar Peter the Great? From a sexual perspective, when in the initial stage of his conversation with Liza, he tries to construct before her a free world for her if she breaks herself free from her profession as sex worker and not be under the control of her customers. However, he shifts his focus and instructs her to get married and have children- married life has been a kind of oppression for numerous women and reproductivity is something which much later Simon De Beauvoir in her Second Sex terms as a form of 'slavery' for women. Therefore, is he trying to emancipate Liza or attempting to make her a serf in a different way? Underground, according to Christianity is where Satan along with his fellow Fallen Angels dwell. Satan rebelled against God and was banished to Hell and can be comprehended to be nothing less than a serf as he was doomed to reside forever in Hell and tied with it much like a serf who was tied to a land of the landlord. The question we therefore ask ourselves is that whether the Underground Man too was banished and compelled to retreat to the Underground because of his momentary attempts to escape control and enjoy freedom?
\end{abstract}

Keywords—serfdom, serf, rationality, will. 


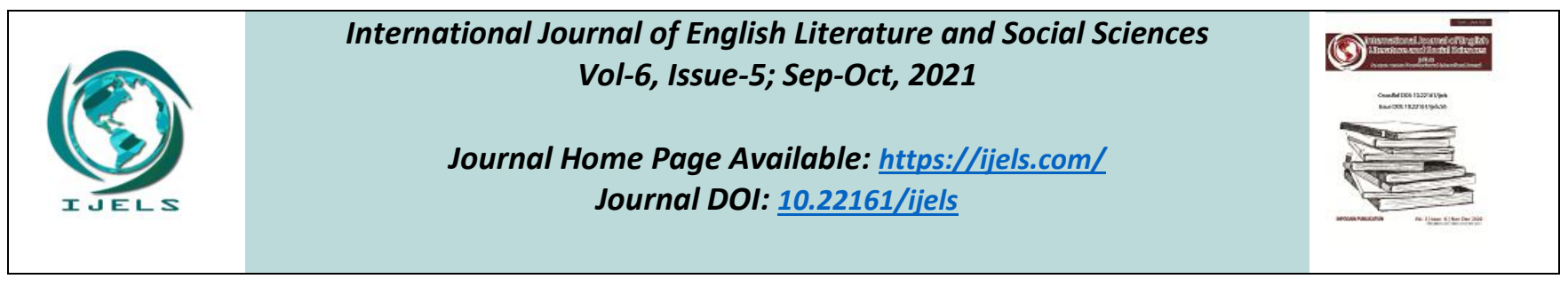

Our prime attention in this paper would be to highlight how the Underground Man from Notes from Underground is an amalgamation of dispositions which portrays him both as a serf and concomitantly as someone trying to break free from control. We shall take into consideration the psychological (rational and consciousness), social, economic and sexual aspects.

Russia, as compared to Western Europe was quite unprogressive and unsophisticated. Tsar Peter the Great's extravagant attempts to modernize Russia and his commendable efforts in making a strong Russian hold in the Baltic region by constructing a naval force even though aggrandized the country but its development in the following years could not be acknowledged to be at par with England or France. The Feudal hierarchy in Russia placed the Serfs at the lowest rank and the Tsar or the Emperor at the top. 'Serf' referred to a peasant in Tsarist Russia who was not free but could be sold only with the land to which he/she was attached or tied to which marks their difference with a slave. Serfdom was a system of intertwined

relations between the landlords who possessed the land and the peasants who populated and worked it. These relations were characterized by a multiplicity of legal, economic, social, sociopsychological, cultural, and political realms, the sum of which made Russian serfdom the remarkably complex societal institution it was. In its fullness, the institution endured for more than two centuries (Gorshkov, 2005, p.2).

What is quite astonishing is that Russian Serfdom was emerging during the sixteenth century, a time when similar institutions were collapsing in rest of Europe and the aristocracy in the early modern period in Russia comprehended the enslavement of the peasants to be the most suitable way to confront the difficulties of the period and insisted the state to acknowledge and respond to this(Gorshkov 3). A catalogue of proclamations from the sixteenth century onwards constrained "the peasants' territorial mobility and subjugated them to the landlords' authority" and the Law Code of 1649 was another impediment since it hindered the movement of the peasants from their residence without adequate authorization and Serfdom then matured and developed in the seventeenth and eighteenth centuries which followed its decline in 1861 (Gorshkov, 2005, p. 3).
Peer-Reviewed Journal

In Fydor Dostoevsky's Notes from Underground, we are introduced to the forty years old Underground Man's perceptions and apprehensions, in the first part of the novella by the means of his diary entries. The second part narrates some of the accounts from the Underground Man's life. Russia witnessed the emancipation of the Serfs in 1861 under Tsar Alexander II and this novella was published in 1864. In the second part of the novella a much younger Underground Man of twenty-four encounters us and therefore we can conceive the fact that the circumstances narrated in the second part which reminiscences the past actually took place when Serfdom was still prevalent in Russia.

In the sixteenth and the seventeenth centuries, the laborers in possession of the gentry were categorized into two different classes- the slaves and the serfs where the slaves were predominantly used in household services while the serfs were assigned to cultivate the land (Vernadsky, 1939, p. 321). The serfs were bonded to the land but not to the land owner at a personal level unlike the slaves who were the properties of their master which however changed as Tsar Peter the great abolished slavery and under him the two groups coalesced and unitedly came to be known as serfs (Vernadsky, 1939, p. 321). The restrictions thrusted upon the serfs by the Legal Code of 1649 dwindled the connection between the serfs and the land and virtually dismissed the probabilities of the peasants' legal escape from their status and moreover, "increasingly, serfs were sold without regard to their attachment to the land" (Hine, 1975, p. 378-379). Like the American slaves there was total ascendancy of the masters over the Russian serfs who had no civil or legal rights (Hine, 1975, p. 379).

We shall first look into the psychological (rational and consciousness) and social aspects together since they are intertwined. It is a promulgated fact that Nikolai Chernyshevsky's What is to Be Done? propounded a Utopian society constructed on the concept of "natural" laws of self interest where rationality and logic preponderate and Dostoevsky's Notes from Underground is perceived as an attack to these ideologies with a constant demur of principles of rationality and reason. What is to Be Done? "laid out the case for a rational ethic of self-interest, a utilitarian system that showed how human beings are by nature determined to choose what is most in their own selfinterest" (Leigh, 2013, p. 91) but the Underground Man 
argues that there have been men who even though had complete knowledge of their "real interests have left them in the background and have rushed headlong on another path, to meet peril and danger, compelled to this course by nobody and by nothing..." (Dostoevsky, 2008). According to the underground man, man creates, or attempts to create, the 'crystal palace', a system in which everything is worked out with "mathematical exactitude, 'in which all questions are answered rationally'-. . .everything will be extraordinarily rational" (Bell, 1977, p.136).Rationality or dependence upon logic according to the Underground Man abbreviate the scope of human will to operate and he under no circumstance is ready to accept a society where every step, every decision becomes a product of mathematical and logical calculation. If we delve deep into this idea indeed it sends a shiver down our spines when we think of a society where nothing but logic prevails and governs over everything. Tender human emotions like love, the most beautiful feeling perhaps, will find the atmosphere unsuitable for it to spread its wings since it galvanizes humans to undertake actions which logically may seem futile. The Underground Man here sharply contradicts Plato who comprehended that logic or the rational portion of the human soul is to be endowed with the governing authority and this is one of the reasons for him to repudiate poetry in his Ideal State because he feels that poetry "establishes a "vicious constitution" in the soul, setting up emotions as rulers in place of reason" (qtd. in Habib 28). Reason, argues the Underground Man "is an excellent thing...but reason is nothing but reason and satisfies only the rational side of man's nature" (Dostoevsky, 2008). Since our childhood days, we get very well acquainted to one belief- our mistakes become the experiences which develops us as a human. In a world constructed with logic, where everything is calculated mathematically according to self-interests and individual advantages will there be the scope for us to conduct mistakes and enhance our understanding of life? Moreover, acting unalloyedly out of one's interests will make us selfish and then gone will be the days when brotherhood and selflessness governed human decisions. The Underground Man'sact of defying rationality occurs at the commencement of Part Iof the novella where he announces that despite being sick, he won't consult a physician and it can be clearly understood that consulting the doctor would have been a step which anyone suffering from illness would reasonably make but since his desire is to dismiss reason he refuses to get treated by a doctor. This is even more pellucid in Part II of the novella when in his young age he encroached upon the plan of his acquaintances from school and forcibly became a part of the dinner but found himself not paid adequate attention. Any rational person would have got up and left the place but since the Underground Man has thoroughly embedded in himself the obstinacy to contravene what is logical and rational, he despite realizing "I must get up at once, this very minute, take my hat and simply go without a word ... I'll go this minute!" (Dostoevsky, 2008) failed to desert the place because by doing so he would have to listen to what reason dictates but he couldn't allow it to be triumphant over his heart's will. The Underground Man talks about enlightenment which will enable men to acknowledge his interests but he abominates self-interest to be the cynosure. It is imperative that we draw the reference to Kant's essay "What Is Enlightenment?" in this context- Kant in his essay, argues that enlightenment will vouchsafe upon humans the autonomy to make use of his own rationality and reason to formulate his decisions. The Underground Man however, asserts freedom too but he abhors the dictums of rationality and voices for the flow of free human will. This is where we can draw the reference of the Russian Serfs who as we have already discussed were not slaves but were controlled by their respective landowners- "it was a visionary serf...who entertained any realistic thoughts of freedom or manumission" (Hine, 1975, p. 379). The Underground Man vehemently refuses to be a serf and submit to the absolute control of his rationality which will vanquish his free will. At this juncture, there is one question that arises- is this belligerence towards a Utopian society constructed on the principles of rationality and logic stem exclusively from the desire to empower the free flow of human will or is he hinting or rather endorsing his affinity for a Dystopian society? Dystopia is a term which was coined in opposite to Utopia and is an imaginary state or society where suffering or injustice predominate ${ }^{1}$. We cannot completely abrogate this possibility. In Part I the Underground Man says, "even in toothache there is enjoyment...enjoyment of the sufferer finds expression in those moans..." (Dostoevsky, 2008). To search for enjoyment in suffering may seem paradoxical to us as readers and suffering we must remember is one of the pillars of a Dystopian society. We have seen how reason alone cannot suffice for human existence but with everyone asserting their heart's will and doing whatever they feel like doing will bring down complete chaos in the society. While it is true in Part I when the Underground Man says:

as to affirm, for instance, following Buckle, that through civilisation mankind becomes softer, and consequently less bloodthirsty and less fitted for warfare... Now we do think bloodshed abominable and yet we engage in this

${ }^{1}$ From [or The Data in column 1] Oxford Concise Companion to English Literature, (p. 212, 741), Dinah Birch and Katy Hooper (Edts.), 2012, United Kingdom: Oxford University Press. 
abomination, and with more energy than ever...these are barbarous times too...that though man has now learned to see more clearly than in barbarous ages, he is still far from having learnt to act as reason and science would dictate (Dostoevsky, 2008).

What he basically means is that reason should have interdicted men from engaging in bloodshed and war but it has failed and men have acted according to their own will thereby countermanding rationality. We can analyse a situation in this context to support the Underground Man's argument- the British Government and the leaders of the Indian National Congress and the Muslim League, who were thought to be men of reason and rationality but who contemplated that Hindus and Muslims need distinct countries for themselves after independence and their decree to divide the country ushered in a time of communal disharmony, displacement, riots, bloodshed, destruction, rapes, and a complete anarchy. Thousands of people were rendered homeless overnight. If truly they would have applied rationality, then could this loss and affliction not have been prevented? Manto's "Toba Tek Singh" in fact portrays that the so called 'lunatics' were not even spared from being moved from one place to another in the name of religion. The Underground Man tries to justify that human will has always been dominating reason but don't we as humans hope to build a society where truly reason will proscribe men to impede actions which welcomes annihilation?We cannot confute the fact that it is exigent for logic and rationality to dictate over human thought at times if not always. But the Underground Man not even for once thinks to accept the sovereignty of rationality and therefore surfaces the question as to whether there is a feeble suggestion of, he supporting the philosophy of a Dystopian society.

In this context, however, his subjugation to his consciousness inexorably enters the discussion and as we proceed, we shall discern the relationship between his action of violating rationality and his excessive consciousness. Bakhtin argues, "Dostoevsky sought a hero who would be occupied primarily with the task of becoming conscious, the sort of hero whose life would be concentrated on the pure function of gaining consciousness of himself and the world. And at this point in his work there begin to appear...the "underground man"" (Bakhtin, 1984, p. 50). Bakhtin clearly refers to the Underground Man of Notes from Underground. In Part I of the novella, the Underground Man narrates that "to be too conscious is an illness" (Dostoevsky, 2008) and that "the direct, legitimate fruit of consciousness is inertia"(Bakhtin, 1984, p. 16) yet he himself is an acutely conscious man and according to Bakhtin "What the Underground Man thinks about most of all is what others think or might think about him; he tries to keep one step ahead of every other consciousness, every other thought about him, every other point of view on him" (Bakhtin, 1984, p. 52). We shall analyse this with regard to the instances that we encounter in Part II of the novella. The twenty-four years old Underground Man despised his colleagues at office and postulated that "my companions looked upon me, not only as a queer fellow, but even looked upon me- -I always fancied this--with a sort of loathing" (Dostoevsky, 2008) and himself justified by saying "owing to my unbounded vanity and to the high standard I set for myself, I often looked at myself with furious discontent, which verged on loathing, and so I inwardly attributed the same feeling to everyone" (Dostoevsky, 2008). Out of his excessive consciousness he surmised that even his colleagues looked down upon him with a sort of repugnance however, we can never know whether they did or not. Again, in the Tavern incident, it was his self-consciousness which invigorated him to think that the officer conceived him to be too inferior to take notice of him and this enrages him. The next incident occurred when he forcefully intruded into the plan of his friends to give a farewell to one of their acquaintances Zverkov, whom the Underground Man detested.He went to the restaurant selected for Zverkov's farewell dinner and to his utter dismay, "No one paid any attention to me, and I sat crushed and humiliated... I must get up at once, this very minute, take my hat and simply go without a word... I'll go this minute!" (Dostoevsky, 2008).But in reality, he remained and as he had already declared that an acutely conscious man is not a man of action but a man of heart, he repudiated what reason prompted and even when he was ignored, he decided to stay to assert his heart's will and because his consciousness conferred in him a state of inertia. Out of his over consciousness again he insulted Zverkov when it was absolutely unnecessary just in order to portray his superiority. There is no way in which we can stay incognizant to the irony which arises when the same man who is so passionately yearning for freedom had been tyrannical as a friend which hehimself confessed- he finally found a friend but

I wanted to exercise unbounded sway over him; I tried to instil in him a contempt for his surrounding. ... He was a simple and devoted soul, but when he devoted himself to me entirely, I began to hate him immediately and repulsed him as though all I needed him for was to win a victory over him, to subjugate him and nothing else(Dostoevsky, 2008).

Even though he impinged where he was quintessentially unwanted yet he "dreamed of getting the upper hand, of 
dominating them, carrying them away, making them like me - if only for my 'elevation of thought and unmistakable wit'. They would abandon Zverkov, he would sit on one side, silent and ashamed, while I should crush him"(Dostoevsky, 2008) and envisaged- "they shall all go down on their knees to beg for my friendship"(Dostoevsky, 2008).

The Feudal hierarchy of Tsarist Russia placed the serfs at the lowest rank and even the least wise person can contemplate that the masters considered them to beinferior. The Underground Man's endeavours to break free from the serfdom of rationality harbingers the notions of liberty and independence but his remarkably opposite confessions where he envisioned himself in the superior position as already mentioned vividly limns the ambiguity in his disposition. What is also to be noted is that a person who revolts against the doctrines of reason and strives to break free from its shackles to assert the liberty of his will is concomitantly a serf to his consciousness and accepts the ordinance of this master.

Secondly, we shall look into the economic aspects and we shall see how rationality and the economic aspects of the Underground Man are interconnected. The 'obrok' and the 'barschina' were two concepts associated to Russian Serfdom- "the obrok was a quitrent paid in cash or kind by the serf to the master while the barschina was a labour obligation to work the owner's land for a specified period of time, usually on a three day per week basis. Almost all serfs undertook one of the two obligations" (Hine, 1975, p. 380-381). 30 and 50 percent of their annual income were paid by the serfs as rent but this also ranged between 17 and 86 percent which depended on the area of the land and the economic condition of the serfs (Gorshkov, 2005, p.10). Serfs discharged labour duties in those places of Russia where agriculture dominated the economy (corvée, known in Russian as 'barschina'), working as we have discussed thrice a week (Gorshkov, 2005 , p. 10). In those places of Russia where agricultural and non-agricultural pursuits commingle, peasants paid rent and this rent and corvée were the two pivotal appurtenances of the landlords to exploit the serfs and those serfs who paid rent enjoyed an increased liberty from the landlords and this "aided these serfs in their own independent economic pursuits" (Gorshkov, 2005, p. 10). The Underground Man was more like a barschina who worked in the Civil Servants Office but the only difference was that it was not done to pay any rent as the serfs did but was done to earn his living. In Part II he expresses "I, for instance, genuinely despised my official work and did not openly abuse it simply because I was in it myself and got a salary for it" (Dostoevsky, 2008). The serfs were tied to their respective lands and the Underground Man has to work in an office even though he execrates it because it provides him with a salary and therefore in a way he too is attached or tied to his job and his financial or economic condition which is weaved by the job and acts like a serf. The young Underground Man's financial status was not that of an aristocrat but this couldn't constrain him to spend money according to his desire or will. He quite unceremoniously encroached into Simonov, Trudolyubov and Ferfitchkin's plans of giving Zverkov, one of their friends, a farewell dinner just because he felt like and went on to express his desire of contributing seven roubles for the expenses when in reality "I had no money. All I had was nine roubles, I had to give seven of that to my servant, Apollon, for his monthly wages" (Dostoevsky, 2008). Even though he did not possess enough money, he travelled to the venue of the dinner in "a high-class sledge, on which I spent my last half rouble, I drove up in grand style to the Hotel de Paris" (Dostoevsky, 2008). To any normal person this will seem to be bizarre. We have seen in Sense and Sensibility how by dint of their new income of not a very handsome amount, Elinor Dashwood and Mrs Dashwood found difficulties to get a new house for themselves along with Marianne and Margaret. This attitude did not bewilder us since we think it is rational to make choices according to what we can afford. But here the Underground Man's attitude can be evaluated as his contumacy to act according to reason and act as his heart wished.

All his attempts that we have discussed so far where he continuously tried to break free from the authority of rationality and then economy and rationality concurrently can also be acknowledged with reference to certain events in Russian history. To draw a comparison here we need to focus on Russian history again- when Tsar Peter the Great declared war on Sweden, which at that time happened to be the strongest force in the Baltic region, $\mathrm{St}$ Petersburg, a mosquito ridden marshland functioned as the military base and because it provided an easy access to the Baltic Sea, St Petersburg became the base for the construction of the Naval force under Peter the Great (BBC, 2018, 39:02-45:00). Russia defeated Sweden at Poltava, Ukraine and after three years in 1712, Peter made St Petersburg the new Russian capital thereby eclipsing Moscow for more than two centuries and under Peter's command, colossal number of nobles and wealthy citizens, had to transpose themselves from Moscow to St Petersburg (BBC, 2018, 48:12-48:38). The city demanded to be constructed, since it was inhospitable for human settlement and in the wake of these forty thousand peasants were conscripted to the new city to build it every year and thousands of serfs and forced labourers perished to meet Peter's desire to build the new city and many of the serfs 
and labourers actually fled during their journey, some fled into the forests once there in St Petersburg (BBC, 2018, 49:39-50:40). In 1773, there was the Pugachev rebellion, named after its leader which inaugurated

first as a local mutiny in the Cossack settlements in southern Ural, it spread like wildfire west toward the Volga and beyond, drawing into its vortex the masses of serf peasantry. Numerous jacqueries characterized the uprising, sowing panic among the officials and landowning class, many of whom were killed while their estates were pillaged by rebels. It required a powerful army to quell the rebellion. The nightmare of this "Russian mutiny, terrible and senseless," in the words of Pushkin, long haunted the Russian landowning gentry (Volin, 1943, p.49).

These were their attempts to break free from control, from authority and so did the Underground Man attempted to break free from rational and economic control.

In Russia, there were two categories of serfs- one category was owned by the State and the second category was of private serfs and it was comprehended that the private serfs suffered from more restrictions than the State serfs (Hine, 1975, p. 379). In this paper we have evaluated the Underground Man as a private serf to his consciousness as well as his economic condition and not to mention rationality, inherently connected to both of them and by defying the dictums of which to destroy the shackles of control he eventually got constrained by his excessive consciousness and attempted to break free from economic serfdom.

Let us now focus on the sexual aspects where Liza is equally important asthe Underground Man and the instances, we shall focus upon are from Part II of the novella. In search of Zverkov and others, the Underground Man came across Liza who happened to be a sex worker. He tried to paint before Liza the vile life of a sex worker and lectured her "on the depravity and worthlessness of her profession" (Walker, 1962, p.201). He argued:

But if you were anywhere else, living as good people live, I should perhaps be more than attracted by you, should fall in love with you, should be glad of a look from you, let alone a word; I should hang about your door, should go down on my knees to you, should look upon you as my betrothed and think it an honour to be allowed to. I should not dare to have an impure thought about you. But here, you see, I know that I have only to whistle and you have to come with me whether you like it or not. I don't consult your wishes, but you mine (Dostoevsky, 2008).
- this literally summarized Liza's life as a serf where regardless of her approbation she had to act according to the wishes of her customers. The Underground Man believed that its not solely her body but her soul too that Liza sold and which he comprehended she had "no right to dispose of" (Dostoevsky, 2008). The inefficacy of her chances to find love in this profession of hers is expressed by the Underground Man when he argued,

You give your love to be outraged by every drunkard! Love! But that's everything, you know, it's a priceless diamond, it's a maiden's treasure, love--why, a man would be ready to give his soul, to face death to gain that love. But how much is your love worth now? You are sold, all of you, body and soul, and there is no need to strive for love when you can have everything without love. And you know there is no greater insult to a girl than that, do you understand? To be sure, I have heard that they comfort you, poor fools, they let you have lovers of your own here. But you know that's simply a farce, that's simply a sham, it's just laughing at you, and you are taken in by it! Why, do you suppose he really loves you, that lover of yours? I don't believe it. How can he love you when he knows you may be called away from him any minute? (Dostoevsky, 2008).

In order to justify and persuade her to denounce her profession as a sex worker "he related incidents of disease, poverty and death which had occurred in the sordid lives of other prostitutes" (Walker, 1962, p.201). Life as a sex worker at that timewas indeed a life of serfdom where one had to comply to the demands of their concupiscent customers who could inflict upon them even immense physical pain and exploit them physically or sexually according to their vagaries much like the masters who “...punished serfs at their whims" (Gorshkov, 2005, p. 5). Despite the agony and excruciating pain there, the sex workers could never complain against the violence much like the serfs who could not complain to the authorities "law prohibited the serfs from complaining against their masters" (Volin 43) even if the laws that were formulated for them were violated by the masters. Today of course, the sex workers have formed organisations that try to protect them from undesirable violence but we are here talking about a time when no such organisations or even the ideology that sex workers too are humans and need to be treated like one did exist. The Underground Man tried to emancipate Liza, to make her realize that she must stop extirpating her life and liberate herself from this dominance. The problem however arose when he offered marriage as an alternative to her present circumstances and presented it as a virtuous choice for her and not to mention 
for women- "You are still young, good-looking; you might love, be married, be happy..." (Dostoevsky, 2008) to which Liza sharply retorted "Not all married women are happy" (Dostoevsky, 2008). He tried to present before her an enthralling married life infused with love, care, ecstasy and delectation-

And how sweet it is to make up after quarrels, to own herself in the wrong or to forgive him! And they both are so happy all at once--as though they had met anew, been married over again; as though their love had begun afresh. And no one, no one should know what passes between husband and wife if they love one another. And whatever quarrels there may be between them they ought not to call in their own mother to judge between them and tell tales of one another. They are their own judges. Love is a holy mystery and ought to be hidden from all other eyes, whatever happens. That makes it holier and better. They respect one another more, and much is built on respect. And if once there has been love, if they have been married for love, why should love pass away? Surely one can keep it!... The first phase of married love will pass, it is true, but then there will come a love that is better still. Then there will be the union of souls, they will have everything in common, there will be no secrets between them. And once they have children, the most difficult times will seem to them happy, so long as there is love and courage (Dostoevsky, 2008).

The exclamations- "if the husband is a good one, loves you, cherishes you, never leaves you" (Dostoevsky, 2008) and "if the husband is kind and straightforward, why should not love last?" (Dostoevsky, 2008) is unmistakably patriarchal where the husband is the determiner of the happiness and we can't help but refer to Simone de Beauvoir's The Second Sex where she explains that Masculinity is fathomed as the "absolute human type" (qtd. in Habib 683). She articulates that "humanity is male and man defines woman not in herself but as relative to him; she is not regarded as an autonomous being . . . she is the incidental, the inessential as opposed to the essential. He is the Subject; he is the Absolute - she is the Other" (qtd. in Habib 683). The two proclamations of the Underground Man itself testifies the fact that marriage as far as his conceptions are concerned cannot be an institution which guarantees women their freedom but obviously the Underground Man did not acknowledge this and reiterated what conventional society believes. Now to develop Liza's argument that "Not all married women are happy" (Dostoevsky, 2008), we can site instances from literature. Kate Chopin's short story- "The Story of an hour" narrates Louise Mallard's emotions and response to the news of the death of her husband and breaking the stereotypical norms which expects her to weep uncontrollably, get engulfed by melancholy and feel completely despondent she exclaims "Free, free, free!" (Chopin) and with all the warmth of her heart tries to embrace her newfound liberty as if marriage had been a prison or slavery or serfdom for her from which she got liberated with the death of her husband. In Rajmohan's Wife, we witness the marital relationship of Matangini and Rajmohan where Rajmohan is the typical patriarchal by product who is excessively jealous, churlish and considers his wife as a commodity almost bequeathed to him. Here it is indisputably clear that Rajmohan considers Matangini no less than his slave or serf. Even though the Underground Man acquiesced to Liza's utterance by "Not all, of course, but anyway it is much better than the life here. Infinitely better" (Dostoevsky, 2008) but evaluated it to be a better prospect. But the question we can ask him is that is dominance, slavery or serfdom be it in any form, justifiable and is it possible ever to acknowledge one to be better than the other especially when he himself is trying hard to break free from serfdom in more that one domain? He then suggested Liza the advantages of having children-

And once they have children, the most difficult times will seem to them happy, so long as there is love and courage. Even toil will be a joy, you may deny yourself bread for your children and even that will be a joy, they will love you for it afterwards; so you are laying by for your future. As the children grow up you feel that you are an example, a support for them; that even after you die your children will always keep your thoughts and feelings, because they have received them from you, they will take on your semblance and likeness. So you see this is a great duty. How can it fail to draw the father and mother nearer? (Dostoevsky, 2008)

Although he askedher "Are you fond of little children, Liza?" (Dostoevsky, 2008) but did not wait for her reply but goes on saying that "I am awfully fond of them" (Dostoevsky, 2008). It might so happen that Liza was not fond of children but then conventionally motherhood and reproductivity has been acknowledged to be an indispensable component of femininity. In Shakespeare's Macbeth, Lady Macbeth at least in the initial stages of the drama is more intrepid and courageous and even goes on to invigorate Macbeth and quell his cowardice to ensure the murder of King Duncan which would make Macbeth the King of Scotland and fulfil the witches' prophecy but Macbeth's words of appreciation for Lady Macbeth commences with "Bring forth men-children only" 
(Shakespeare 1.7.72) and it's more like a reminder that being his wife her preliminary duty is to produce an heir before everything else and hence reproductivity (ovaries and uterus) again reinforces itself. Years later from the composition of both Macbeth and Notes from Underground, Simone De Beauvoir in The Second Sex defines reproduction as a "slavery" (qtd. in Habib 689) for women. What we also must remember is that what Jerome Blum observes,

Life as a house serf was often the harshest and the most demoralizing of all peasant experiences. Living as they did in constant contact with their lords who had complete control over them, they were much more liable than other serfs to frequent - and sometimes frightful - punishments from captious lords and mistresses, while the women among them were often misused by lecherous masters (qtd. in Hine, 1975, p. 381).

Liza's sexual exploitation in her profession was guaranteed but no one could guarantee that she would not be sexually exploited by her husband too either because of his natural disturbing disposition or to have more children or both. However, there was no such conception of 'marital rape' at Dostoevsky's time and therefore as Liza could not complain against the wrongs inflicted upon her by her customer, similarly she could never complain against her husband's inactions too much like the serfs who could not complain against their masters. The question we can ask the Underground Man is that wasn't in the process of emancipating Liza from the serfdom that her profession as a sex worker thrusted upon her, he was actually stimulating her to enter into a different kind of serfdom by the name of marriage and reproduction? Moreover, what is perplexing is that the Underground Man who himself searched for occasions to break free from serfdom of more than one kind (internally related), actually went on to try and establish his superiority as master over Liza by offering her money and this is what he did with the one friend he got and with his servant Apollon too- he tried to assert his dominance and prove himself to be tyrannical and despotic and rendered himself the impotency to form social relationships be it as a friend or as a lover or being a good master to his servant whom perhaps he considers more as his serf (exercise dominance). In Liza's case however, she emerged to be the Underground Man's superior as she embraced him with her heart's warmth even though he tried to humiliate her and then returned the money offered to her- she outshone him as a human being. Its ironical to see a person trying to break free from control is himself turning the equation and trying to be the controller at times and this is again where the issue of "unfinalizability... unclosedness and...indeterminancy"
(Bakhtin, 1984, p. 53) evolves as we cannot categorize the Underground Man as a serf or as a master with absolute control.

The masters could "punish them in all sorts of ways: whip, beat, and even exile them to Siberia, draft them into the army or sell them" (Volin, 1943, p. 42)-them refers to the serfs. In Christianity, underground is believed to be the place where lies Hell in which Satan formerly Lucifer dwell with his companions- the other fallen angels who rebelled against God. Lucifer or Satan was punished by God for his revolution and was banished forever in Hell. Satan is tied or attached to Hell exactly like the Russian serfs who were attached to their lands. The Underground Man tried to break free from control and rebelled and the question that we can therefore try to find an answer to is that whether he too was banished to reside in the underground forever as a punishment because of his attempts to escape and also because the society faces difficulty in accommodating him? Moreover, the Underground Man was defying the principles of rationality by residing in St Petersburg which "with its canals and stone buildings resembling Venice or Amsterdam, St Petersburg presented foreign visitors with Peter's vision of a modern Europeanized Russia, one full of thriving commerce and 'rational order'" (BBC, 2018, 48:4149:15)- Peter here refers to Tsar Peter the Great. Satan could not be the sovereign of Heaven but he rules over Hell where he is the master or the monarch. Similarly, the Underground Man can assert his will and dominance unquestionably in the underground where he need not consider anyone. Even though serfdom in Russia was abolished in 1861 and the serfs were emancipated neither Satan nor the Underground Man could respectively leave Hell or Underground.

\section{CONCLUSION}

We could therefore observe how the Underground Man is concomitantly a serf and is trying to be free from certain constraints and what we realize is that we cannot define or categorise him and this attribute of his character is perhaps, what makes him so unique, so different. We are also perplexed when we try and analyse his attitude to Liza as we cannot discern concretely as to whether he wished to emancipate her or push her into a new serfdom. The Underground Man cannot be categorised under one particular disposition and this evaluation attempts to rejustify that and open new horizons for further understanding of the Underground Man's character by referring to Russian history.

\section{REFERENCES}


[1] Bakhtin, M. (1984). Problems of Dostoevsky's Poetics. Edited and Translated by Caryl Emerson, Introduction by Wayne C. Booth, vol. 8, University of Minnesota.

[2] Bell, Linda A. (1977). Dialectic in Dostoevsky's Notes from Underground. JSTOR.Journal of Thought,12(2), 136146. https://www.jstor.org/stable/42588630.

[3] Chatterjee, B.C. (2018).Rajmohan's Wife. Book Valley.

[4] Chopin, K. (2014).The Story of an Hour. EPUB, HarperCollins Canada.

[5] Dostoevsky, F. (2008).Notes from Underground. Project Guttenberg. https://www.gutenberg.org/files/600/600h/600-h.htm.

[6] Gorshkov, Boris B. (2005).A Life Under Russian Serfdom: The Memoirs of Savva Dmitrievich Purlevskii, 1800-1868. Central European University Press.

[7] Habib, M.A.R. (2005). Modern Literary Criticism and Theory A History. Blackwell Publishing.

[8] Hine, William C. (1975). American Slavery and Russian Serfdom: A Preliminary Comparison. JSTOR. Phylon, (1960-) 4th Qtr., $36 \quad$ (4), 378-384. https://www.jstor.org/stable/274636.

[9] Austen, J. (2010).Sense and Sensibility. Amazing Reads.

[10] Leigh, David J. (2013). The Philosophy and Theology of Fyodor Dostoevsky. URAM. https://www.utpjournals.press/doi/pdf/10.3138/uram.33.12.85 .

[11] Manto, S.H. (1989). Toba Tek Singh. KINGDOM'S END AND OTHER STORIES(p. 11-18).Translated by Khalid Hasan, Penguin Books.

[12] Oxford CONCISE COMPANION TO English Literature. Birch D., Hooper K (Edts.). (2012).Oxford University Press.

[13] (2018, December 15).BBC Empire of the Tsars Romanov Russia lof 3 Reinventing Russia [Video]. YouTube.https://www.youtube.com/watch?v=73eaNrTX3 CA.

[14] Shakespeare, W. Braunmuller A.R. (Ed.). (2012). Macbeth(First South Asian edition). Cambridge University Press.

[15] Verandsky, G. (1939).Feudalism in Russia.JSTOR. Speculum,14(3), 300-323. https://www.jstor.org/stable/2848599.

[16] Volin, L. (1943). The Russian Peasant and Serfdom.JSTOR. Agricultural History, 17(1), 41-61. https://www.jstor.org/stable/3739549.

[17] Walker, H. (1962).Observations on Fyodor Dostoevsky's Notes from the Underground. JSTOR.American Imago,19(2), 195-210.

https://www.jstor.org/stable/26301863. 